\title{
Affixation Category of Palembang Malay Language Reviewed From Perspective of Morphological Typology
}

\author{
Husni Thamrin \\ English Department Pasundan University \\ Email: husnithamrin@unpas.ac.id
}

\begin{abstract}
This research is related to affixation category of Palembang Malay language, which is a regional part of the Sumatra region exactly South Sumatra. In particular, this study uses category of affixation in the form of prefixes and suffixes (suffiks) used by Dryer's (2013) in researching the Nualu language in Seram island which belongs to the Polynesian Malay ethnic. This research reveals that on Palembang Malay language affixation, the first affixation category was the form of 6 (six) categories of prefixes (awalan) in Palembang Malay language, among others; N-, di-, peN-, be-, te-, and se-.Second, there are found 5 (five) types of suffixes (akhiran) in Palembang Malay language, such as; -ke, -la, -an, -nyo, and -i. The third is found 3 (three) simulfix (awalan-akhiran) which is the type of bound form of the prefix one with another prefix, such as: ke-.. . -an, pe-... - -an, and be-. -an. Finally, there were found 3 (three) main categories of morphophonemic process prefixes in Palembang Malay language, such as; a) there are four types of prefixesN-in Malay language Palembang has many allomorphs: $\mathrm{m}, \mathrm{n}$, ny, ng. b) there are six types of prefixespeN- connected with words, so the prefix will change to: pem-, pen-, peny-, peng-, pel-, orpe-. c)there are four prefixesbe- that has allomorphs bel-, ber, and be- .The Grand theory approach used in this study has been stated by Velupillai (2012) and Lieber (2009).
\end{abstract}

Key words: affixes, prefixes, suffixes, simulfix, typology

\section{Introduction}

Velupillai (2012, p.91) explains

that there are four categories of affixation. The first is the prefix (awalan) which position is attached to the beginning of the word for example in English in the derivational prefix un-, in the word happy to be un-happy. Second, suffix attached to the end of a word, for example the suffix -ness of the word happy becomes happi-ness. Third, infix which is a suffix whose position is in the middle of a word or morpheme which is considered the root word. For example in the language Leti (Austronesian (Central MalayoPolynesian): Indonesia), in the verb in the form of infix (sisipan), this is, from the word kakri 'to cry' (cry) to>kniakri (k-ni-akri) '(the) act of 
crying' (crying). From this explanation, it can be understood that Malay language belongs to a group of agglutinative languages, namely language which consists of more than one morpheme attached to the base of the word. At least the morpheme form consists of various types of word class forms that can be seen in terms of the phonetic form directly. Comrie (1989, p.43)

In Indonesian, there are four types of affixation, namely prefix, infix, suffix, and there is a combined embodiment of the prefix and suffix in a word called confix or some say it with simulfixes or circumfixes. There are many studies of various types of language typologies in the world that explain the affixation process in terms of inflectional and derivational morphemes, but from these various studies most only discuss one perception about prefixes or suffixes only (see, Blench, 2012. Marelli, 2012. Sailor \& Mahajan, 2012. Hillips \& Lewis, 2013. Jaques, 2015. Creemers, 2017.Wiemer \& Serzant, 2017.Bunau,
2018. Cotterrell.et all, 2018. Regel \& Opitz, 2018. There are only a few studies related to affixation that discuss about prefixes and suffixes, for example, examined by Dryer's (2013), prefixes by Romli \& Wildan (2015) contrasting Indonesian and Sundanese languages, and Tambusai et.all (2016) examined affixation only in Riau Malay language. but there has not been a study that addresses the affixation of Malay language in Palembang in the regional regions of Sumatra. The proposed questions in this study are: what types of affixation categories appear in Malay Palembang language. How did the morphophonemic process occur in the Palembang Malay language?

\section{Literature Review}

$$
\text { Meyer (2002, p.154). }
$$

Derivational morphemes can be prefixes or suffixes, whereas inflectional morphemes are found mostly only in suffixes. Generally, the explanation of inflectional 
morphemes is to explain the form of the word suffix by not changing the basic meaning of the word, as the word 'book' is given a suffix -s into books which indicate the plural form of many books or books. While derivational morphemes can change the class group of words and word meanings. For example; addition of prefix dis- (meaning negation/no) to the basic words of verb 'like' so that it changes into a word - dislike - which means doesn't like, which is associated with the opposite word (opposite meaning); by adding a suffix -able to the word 'like' so that it brings changes in verb form like as an adjective: likeable which means it can be liked. It is understandable that there are significant differences from affixation in the form of inflectional morphemes which do not change much in the form and meaning of the basic words. Whereas, derivational morpheme influences the form and change of word class from the change in the basic form of the word.
Lieber (2009, p. 35) Prefixes and Suffixes are usually attached to basic words that are attached to the beginning of the word or at the end of the word. However, the attachment of the prefix and suffix forms is often based on the category of the form of the word structure. For example, the suffix -ness attached to an adjective like the following example. -ness on adjectives: redness, happiness, wholeness, commonness, niceness. While the prefix form tends to be in the form of negation, for example the prefix in English is more likely in the form of the connotation meaning of negation, such as; un-fortune, unlucky.

Infixes are affixes that are stored or inserted in the middle of the root word on the base word. It can be seen in the example of the Tagalog language which is a Malay-Polynesian language in the Philippines. Derived from adjectives by inserting morphemes after consonants that are at the beginning of the base word, for example; g-um-you which means 
becoming beautiful, h-um-irap which means becoming difficult. The morpheme in tagalog language in the Philippines is an infix form. Another type of affixation is circumfix is two parts, each of which is a prefix and suffix attached to the basic word that will form a new word. This circumfix can be seen in the example of the Dutch language, in the collective form of nouns from the category of nouns that can be calculated, the morpheme (prefix) ge- is located before the base word and morpheme (suffix) -te is located after the basic word, like the following example; 'Berg', which means 'mountain', is the circumfix of 'ge-berg-te' meaning 'mountain chain'. The basic word 'vogel' which means bird 'becomes the circumfix of' ge-vogel-te 'which means' flock of birds'. Lieber (2009, p.76-79).

Complete vocabulary can consist of one or more prefixes or suffixes better known as affixation. There is a difference between derivation and inflection (derivation refers to making words, while inflections create a type of word formation) Booij (2005, p.86-79). It is clear that there are significant differences when the morphophonemic process occurs in an inflection or derivation which will change the type of the word base.

Chaer (2008, p. 23). Affixation to the Indonesian language is divided into several types of categories, namely; 1) prefix (awalan), 2) infix (sisipan), 3) suffix (akhiran), and 4) circumfix (gabungan). Alwi (2003, p.26) explains that phonemes are sounds of language which have at least differences in form and meaning. Linguistics explains that the phoneme is written between two slashes: / ... /. As in Indonesian the letters / p / and / b / are two phonemes because the two sounds distinguish form and meaning. Although the phoneme is not a discussion in the form of word formation and it is a categorization of subdisciplines of phonological sciences. It will have a close relationship that cannot be separated 
in the study of morphology, with strong reasons that words are a series of several phonemes that have their own meaning into the basic elements in word formation. Morpheme is the smallest grammatical unit that has the meaning. Chaer (2003, p. 146). It is quite clear that the morpheme is the smallest part which has a special meaning grammatically. In the standard form of the Indonesian language the word 'pe-nelpon' or caller does not consist of a morpheme because it has similarities to the word of 'pe-nari' or dancer. But the word caller separates us from telephone calls (the basic form of telephone is a phoneme / $\mathrm{n} /$ change to / $\mathrm{t} /$ at the beginning of the basic telephone word) so that each has no resemblance to other forms.

Chaer (1994, p. 195) states that morphophonemic or morphonemic, morphophonology or morphonology is the change in morphemic form in a morphological process consisting of elements, namely morphemes and phonemes. Phoneme is the smallest unit of sound that distinguishes meaning, while morpheme is the smallest unit of sound that contains meaning. By phonemes and morphemes are still related to sound, the study or mediates between the two disciplines is morphophonology. Chaer also explains that there are 5 (five) manifestations of phoneme changes in the morphophonemic process, namely; (1) the appearance of phonemes that can be seen in the process of adding prefix to the basic reading form that becomes read; where a nasal consonant / m / appears, (2) phoneme merge can be seen in the process of filling the suffix wan in the historical word where the phoneme / h / in the historical word is lost, (3) phoneme leaching can be seen in the filling process with prefix to the brush word where the phoneme / s / on the brush word is melted and compounded with nasal sounds / from / the prefix, (4) phoneme changes can be seen in the process of adding prefixes to the words where 
phoneme / r / changed to phoneme / l /, (5) phoneme shift is the transfer of a phoneme from one syllable to another, or the next. It can be seen in the suffix /an/ in the answer word where phoneme / b / which was originally in sylable/ wab / move to syllable /ban/ . Ja.wab + an = ja.wa.ban.

Suparman (2008, p. 5) explains that in Indonesian agglutination which is not found in the morphological process data in the form of internal changes, suplisi, and blank modifications. So, the morphological process in Indonesian is only through affixation in the form of affixes. Whereas Samsuri (1985. p.190) explains that affixation is a combination of root words from the prefix, infix, and suffix. There are three types of affixes, namely prefixes, infix, and suffix. The position is always in front of the basic form, the affix is called the prefix or prefix form. Affix is called insertion (infix) because it is located in the word, while the suffix is located at the end of the word.

\section{Methodology}

In Indonesian, there are three types of affixation, namely prefix, infix, and suffix. The method of this research is carried out by a combination of qualitative and quantitative methods (mixed method) see (Cresswell 2008). Referring to the subject matter of the question in this study, as for the source of the data collected in the form of dialogue is the conversation of the Malay language of Palembang by means of literature studies and recording dialogue conversations directly from Palembang Malay-speaking families. The dialogue is then copied according to the original. This study involved several relatives of researchers who were taken purposively, namely those who every day often had conversations in Palembang Malay language. 


\section{Discussion}

1. Palembang Malay Language Affixation

In Palembang Malay language, affixation of morpheme forms are free and some are bound. Dunggio (1983, p. 35) explains that in the Malay language there are many morphemes that can stand alone and there are also morphemes which are bound to other words. These standalone morphemes, among others: wong, umo, idup, cari, dio, and tigo. Morphemes that are bound to other words, for example; $N-$, di-, -nyo, -ke, -la, be-, te-, se-, -i, ke-... -an, pe-.. . an.

\subsection{Prefix (awalan)}

Prefix in Malay language Pelembang, among others $N$-, di-, peN-, be-, te-, and se-.

\subsubsection{Prefix $N$ -}

In sentence No. 1 there is a word nyari consisting of two morphemes. Similarly, the word nyekel in sentence No. 2. Each consists of a free morpheme: nyari and nyekel are added to a prefix. The prefix is denoted by $N$ - which functions as the form of an active verb, that is, the principal sentence moves or acts stated by the verb, for example;

(1) Dio besake anaknyo dengan nyari kayu api di utan.

PRO3SG grewPAST child3SG

PREFsearch firewood PREPjungle

(la membesarkan anaknya dengan men-cari kayu api di hutan)

'He grew his child by searcing firewood in the jungle'

(2) Dio n-yekel duet limopiah.

PRO3SG PREFgets money five rupiahs

(Dia memegang uang limo rupiah)

He gets five rupiahs of money'

\subsubsection{Prefix di-}

In sentence No. 3 there is a word jingok consisting of two morphemes. The same goes for the word nyekel in sentence No. 4. Each consists of a free morpheme: jingok 
and goco are added a prefix (prefix). The prefix can also be represented by $d i$ - used as a passive sentence.

(3) Ayin gi saket di-jingok Mak. Ayin PROGRESS ill PREFseen mother

(Ayin sedang sakit di-jenguk $\mathrm{Ibu})$

'Ayin is being ill seen by his mother'

(4) Maling di-goco Mangcik di pasar tadi pagi.

Thief PREFhit Mangcik

PREPmarket in the morning

(Maling di-tinju Paman di pasar tadi pagi)

'Thief was hit by Mangcik at market in the morning'

\subsubsection{Prefix peN-}

In sentence No. 5 there is word idupan consisting of two morphemes. Similarly, the word arepan in sentence No. 6. On the prfix peN-. this is also influenced by the sound of the beginning of the morpheme where the morpheme is attached. So, the morphophonemic pen will become a nasal sound with the next consonant if the prefix is attached to the forms that begin with the sound of the obstacle or the affricative.

(5) Peng-idupan sehari-hari Udin cuma ngolake umo.

PREF daily activities Udin just work farming area

(Peng-hidupan sehari-hari Udin hanya mengerjakan ladang)

'Daily activities of Udin is just to work at farming area'

(6) Peng-arepan dio anaknyo jadi wong beguno galo.

PREF hope PRO3SG child3SG be good people

(Peng-harapan Dia anaknya menjadi orang berguna semua)

'His hope is his child to become a good people'

\subsubsection{Prefix be-}

In sentence No. 7 there is a cekel word consisting of two morphemes. Similarly, the word kelakar in sentence No. 8. Each 
consists of a free form: cekel and kelakar are added with a form of prefix. The prefix is denoted by bestating that the work or action is taking place, besides it is forming an intransitive verb.

(7) Dio be-cekel dengan tanganku.

PRO3SG PREFhold with myhand (Dia ber-pegang dengan tanganku)

'He held with my hand'

$$
\text { Ulil lagi be-kelakar di Pos }
$$

Ronda

Ulil PROG(Present) PREF speak PREP Pos Ronda

(Ulil sedang ber-bicara di Pos Ronda)

'Ulil is speaking at Pos Ronda'

\subsubsection{Prefix te-}

In sentence No. 9 there is a belah word consisting of two morphemes. Similarly, the word tetak in sentence No. 10. On the prefix te- is also influenced by the sound of the beginning of the morpheme in which it is attached. It states that the action was done accidentally.
(9) Meja belajar adek te-belah jadi tigo.

Table Learn PRO3SG younger brother PREFcut become three

(Meja belajar adik ter-potong menjadi tiga)

'Learning table of younger brother cuts to become three'

(10) Bambunyo te-tetak jadi limo.

Bamboo PRO3SG PREFcut become five

(Bambunya ter-potong menjadi lima)

'His bamboo cuts to become five'

\subsubsection{Prefix se-}

In sentence No. 11 there is a kecik word consisting of two morphemes. Similarly, the word arepan in sentence No. 12. on the prefix se- is also influenced by the sound of the beginning of the morpheme where the morpheme is attached. So, morphophonemic is attached to forms that begin with vowel and consonant phonemes. 
(11) Dio sedekah se-kecikan.

PRO3SG give charity

PREFsimple

(Dia mengadakan kenduri secara sederhana)

'He gives simple charity'

Wak Zul ngomong se-adonyo.

PRO3SG speak PREFsimple

(Paman Zul berbicara seadanya)

'Uncle Zul speaks simply'

\subsection{Sufix (akhiran)}

Suffix in Malay Pelembang language, among others; -ke, -la, -an, $-n y o$, and $-i$

\subsubsection{Sufix -ke}

In sentence No. 13 there is a carike word consisting of two morphemes. Likewise, the word iduplah in sentence No. 14. Each consists of a free form: carike and iduplah are added to a suffix (suffix). In example no. 13 the sufix form $-k e$, it functions as a commandment; in example no. 14 sufix -ke also means to have done something for someone else.
(13)

Cari-ke kayu pengidup api. Find SUFF wood light up fire (Carikan kayu penghidup api) 'find some woods to light up fire

Motor itu da kuidup-ke. Bike D.PRON. Turn on SUFF

(Motor itu telah kunyala-kan)

'that Bike has turmed on'

\subsubsection{Suffix -la}

In sentence No. 15 there is the word baco-la which consists of two morphemes. Similarly, the word sehat-la in the sentence No 16. Each consists of a free form: baco and sehat are added to a suffix (suffix). In no.15 sufix -la is used as a verb form that expresses command, which confirms or weakens. Whereas in number 16 suffix -la can be attached or affixed to several words of circumstances or numbers that give meaning in the form of expectations or express offers 
(15) Baco-la buku resep caro masak pempek lenggang.

Read SUFFbook receipe way cook pempek lenggang

(Bacal-ah buku resep cara memasak pempek lenggang)

'Read the way of receipe book to cook pempek lenggang'

$$
\text { Sehat-la mang Udin, jangan }
$$
sakitan bae.

Get well soon SUFF uncle Udin, don't be ill anymore.

(Semoga sehat mang Udin, jangan mengalami sakit terus)

'Uncle Udin gets well soon, don't be ill anymore'

\subsubsection{Sufix -an}

In sentence No. 17 there is the word motor-motor-an ending in a repetition. The suffix -an is usually associated with a repeated word, including compound word repeats and repeated word combinations with compound words that mean something. In sentence 18 said bulanan which states each. on the suffix $a n$, it is associated with the root noun which states the size, meaning in or each.

Lagi kecik dulu aku seneng main motor-motor-an.

While kid was PRON.SG happy play bikeSUFF

(Semasa kecil saya senang bermain dengan mainan motor-motoran)

'While I was kid, I was happy to play bikes game'

Gaji bulan-an cuma cukup untuk makan seminggu.

Salary monthlySUFF just enough eat a week

(Gaji perbulan hanya cukup untuk makan selama seminggu)

'Montly Salary is just enough to eat in a week'

\subsubsection{Suffix -nyo}

There is word of idup-nyo consisting of two morphemes. suffix is denoted by nyo-, which states the case of someone's ownership. Whereas the word limo-nyo in sentence No. 20 states the total 
number of stated or informed numbers..

$$
\text { Nasib idup-nyo selalu baek }
$$

terus.

Destiny lifeSUFF PRO3SG always good forever

(Nasib hidupnya selalu baik terus)

'His destiny life is always forever good'

$$
\text { Pempek lenjer limo-nyo }
$$
kuborong galo.

Pempek lenjer fiveSUFF buy all

(Limanya pempek lenjer saya beli semua)

'I buy all five pempek lenjers'

\subsubsection{Suffix $-i$}

In sentence No. 21 there is the word cekel-i which consists of two morphemes. The suffix $-i$ describes a third-person pronoun. While the sentence No. 22 The suffix $-i$ states the adjective of an object which means loosening or raising an object.

Cekel-i tangan iwan awas campak.

Hold SUFF hand PRO2SG carefull fall

(Pegang-i tangan iwan awas jatuh)

'Be carefull, please hold a hand of Iwan'

(22) Gek jangan lupo besak-i baju kaos adek.

Don't forget big SUFF T-shirt younger brother

(Nanti jangan lupa besar-i baju kaos adik)

'Don't forget to make bigger younger brother's T-shirt'

\subsection{Simulfix (Awalan-Akhiran)}

Prefixes and suffixes in the Malay language of Palembang can also be combined to form another 
type of bound form, that is: ke-.. . -an, pe-... -an, and be-. -an.

\subsubsection{Simulfiks $\{k e-. . .-a n\}$}

In sentence No. 23 simulffix kelupo-an describes the nature of an object which means accident. While the sentence No. 24 on the simulfix ke-malem-an states the time statement of a situation.

(23) Sampe di sekolah Adut kelupo-an bawa duet.

Arrive PREP School Adut PREFforgetSUFF bring money (sampai di sekolah Adut kelupaan membawa uang)

'Arriving at school Adut forget bring his money'

(24) Kito dah ke-malem-an sampe di Bandong.

PRON3SG hasP.PERF.

PREFnightSUFF PREP Bandung

(Kita sudah kemalaman tiba di Bandung)

'We have arrived at late night in Bandung'

1.3.2 Simulfix $\{p e-. .$. -an $\}$
In sentence No. 25 simulfix of pe--an describes the basic combination of verbs into nouns. While the sentence No. 26 on the simulfix pe-males-an states the description of the condition of the adjective into a repetition form with the simulfix of pe--an.

(25) Dio ke rumah emaknyo cuma pe-singgoh-an bae.

PRON3SG

PREPhouse motherPRON3SG just PREFstaySUFF

(Dia ke rumah ibunya hanya per-singgah-an saja)

'He goes to his mother just for staying'

(26) Gawenyo pemalesan nian tiap hari.

workPRON3SG PREFlazySUFF everyday

(Pekerjaanya hanya malasmalasan saja setiap hari)

'His daily works just do a laziness'

1.3.3 Simulfix $\{$ be-... . -an $\}$ 
In sentence No. 27 simulfix becekel-an explains the basic combination of verbs into nouns. While the sentence No. 26 in simulfix be-limo-an states the description of the whole number of nouns.

(27) Kalu naek motor be-cekel-an yang kuat yo.

If ride bike PREFholdSUFF CONJ tight

(Kalau naik motor berpegangan yang erat ya)

'If ride bike please hold tightly' Be-limo-an bae ke rumah wak cak tu.

PREF.NUM. SUFF just PREPhouse aunt Cak

(Berlimaan saja ke rumah Wak Cak itu)

'Just five people to go to Aunt Cak'

2. Morphophonemic of Palembang Malay language

In Malay language of Palembang also found many phoneme changes caused by the merging of two or more morphemes. Changes caused by the merging of two or more morphemes are called morphophonemic.

\subsection{Prefix $N-$}

Prefix $N-$ in Palembang language has allomorphs: $m, n, n y$, ng. This can be compared with changes in the nasal phoneme in the event of assimilation in Indonesian language. When forms that begin with africative sounds and voiced of prefix $\mathrm{N}-$, then the forms will become a single nasal sound with a consonant. Like the example below.

$$
\begin{array}{lr}
N-+ \text { beli } & \text { 'beli' } \\
\text { meli } & \text { 'membeli' }
\end{array}
$$

\begin{tabular}{cr}
\multicolumn{2}{c}{ denger 'dengar' } \\
nenger 'mendengar'
\end{tabular}

$$
\text { jago 'jaga' }
$$$$
\text { nyago 'menjaga' }
$$

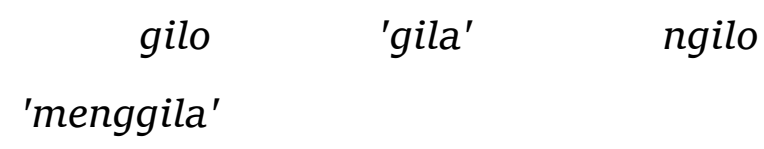




\subsection{Prefix PeN-}

If the prefix peN- is connected with words, the prefix will change to: pem-, pen-, peny-, peng-, pel, or pe-. For example:

$$
\text { peN- + baco }
$$$$
\text { 'baca' }
$$

pemaco

'pembaca'

$$
\text { tulis }
$$

'tulis'

penulis

'penulis'

cari

$$
\text { 'cari' }
$$

penyari 'pencari'

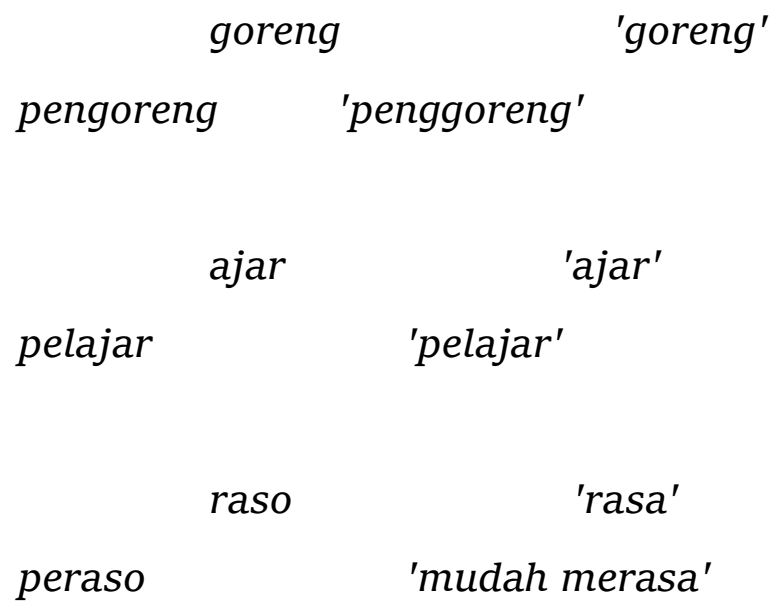

\subsection{Prefix be-}

Prefix has allomorph bel-, ber, and be-. Allomorph bel-only occurs at the root of the teaching (ajar) word; for example;

be- + ajar 'ajar' belajar 'belajar'

beroba 'ubah'

oba 'berubah'

begoco

'tinju'

'bertinju'

\section{Conclussion}

In Palembang Malay language, the first affixation category is found in the form of 6 (six) types of prefixes in Malay language Pelembang, among others $N_{-}^{-}$, di-, peN-, be-, te-, dan se-. Secondly, there are also 5 (five) types of suffix (akhiran) in Malay Palembang language, including; -ke, la, -an, -nyo, and $-i$. The third is found 3 (three) simulfix (prefixsuffix) which is the type of bound form of the prefix one with another prefix, namely: ke-.. . -an, pe-...-an, and be-. -an. The last, there were 
found 3 (three) main categories of the morphophonemic process prefix in Palembang Malay language, such as;

a) there are four types of prefix $N$ - in Malay language Pelembang has allomorphs: $m, n, n y, n g$. b) there are six types of prefixes associated with words, the prefix will change to pem-, pen-, peny-, peng-, pel-, atau pe-. c) there are four prefixes have allomorph bel-, ber, and be-. It is understandable that from the three main categories of morphophonemic processes that occur, there are also detailed explanations of the three main categories of morphophonemics which are outlined in the detailed sub-categories of the occurrence of the morphophonemic process. In Palembang Malay language there is no infix form known as insertion. This could be the language spoken in the daily life of the Malay people is direct and spontaneity which has similarities in affixation in English which does not recognize the form of insertions (infix). Although there are also many forms of affixation in
Sumatra's regional Malay language as in the Aceh Malay language.

This finding is in line with Dryer's (2013) who examined prefixes and suffixes in the Nualu language on Seram Island, but Dryers only discussed prefixes and suffixes.. The research findings of Palembang Malay language affixation are also in line with Velupillai (2012) and Lieber (2009) which explain affixation in the form of (prefixes-infix-suffix) along with (Simulfix). This finding is also in line with Tambusai et.all (2016) who has examined affixation in Riau Malay language which also does not explain much about insertion. It can be understood that almost all of the Malay Malay regional languages know very little about infixation that are not as complete as infix discussions in Indonesian. This Palembang Malay language falls into one of the categories of agglutinative language where many Malay language morphophonemic processes occur inflectional and derivational 
processes at the phoneme level and also in their morphemes.

\section{REFERENCES}

Alwi, Hasan. et. al, 2003, Tata Baku Bahasa Indonesia, Jakarta: Balai Pustaka.

Booij, Geert. (2005). The Grammar of Words: An Introduction to Linguistic Morphology. New York: Oxford University press.

Blench, Roger et.all (2012). The origins of nominal affixes in MSEA languages: convergence,contact and some African parallels. Diakses dari http://www.rogerblench.info/RBO P.htm

Bunau, Eusabinus et.all (2018). Morpheme \{bun-\}: An Example of Morphological Process Through Affixation in Bidayuh-Somu Language. Lingua Cultura, 12(2), May 2018, 203-208 Diakses dari https://doi.org/10.21512/lc.v12i2.3 962 .

Dryer, Matthew S. (2013).Prefixing vs. Suffixing in Inflectional Morphology. In: Dryer, Matthew S. \& Haspelmath, Martin (eds.) The World Atlas of Language Structures Online. Leipzig: Max Planck Institute for Evolutionary Anthropology. (Available online at http://wals.info/chapter/26, Accessed on 2018-12-28.)
Comrie, Bernard. (1989). Language Universals and Linguistic Typology. Chicago: Basill Blackwell Publisher.

Creswell, Jhon.W, 2008, Research Design: Qualitative, and Mixed Methods Approaches, California: SAGE Publications.Inc

Chaer, Abdul, 1994, Linguistik Umum, Jakarta: Rineka Cipta

Cher, Abdul, 2003, Psikolinguistik, Jakarta: Rineka Cipta

Chaer, Abdul. 2008. Morfologi Bahasa Indonesia. Jakarta: Rineka Cipta.

Cotterrell, Ryan et.all (2018).On the Complexity and Typology of Inflectional Morphological Systems.

fryan.cotterell,eisnerg@jhu.edu.

Diakses dari https:// arXiv:1807.02747v1 [cs.CL] 8 Jul 2018.

Cremeers, Ava. Et.all (2017) Some affixes are roots, others are heads. SPRINGER Journal. Received: 20 May 2014 / Accepted: 22 March 2017 / Published online: 5 July 2017

(C) The Author(s) 2017. This article is published with open access at Springerlink.com

Dunggio, P. D. et.all. (1983). Struktur Bahasa Melayu Palembang: Pusat Pembinaan dan Pengembangan Bahasa Departemen Pendidikan dan Kehudayaan Jakarta.

Jaques, Guillaume (2015). Denominal affixes as sources of antipassive markers in Japhug Rgyalrong*. 
HAL Id: halshs-01244876. Diakses dari https://halshs.archivesouvertes.fr/halshs-01244876.

Lieber, Rochelle (2009). Introducing Morphology. New York: Cambridge University

Meyer, Charles. F (2002).Introducing English Linguistics. New York: Cambridge University press.

Marelli, Marco et.all (2012). Affixation in Semantic Space: Modeling Morpheme Meanings with Compositional Distributional Semantics. Diakses dar http//www.modeling Morpheme Meaning with Distributional Semantics.

Phillips \& Lewis. (2013). Derivational Order in Syntax: Evidence and Architectural Consequences* . (C) Copyright 2013 Colin Phillips, Shevaun Lewis STIL - Studies in Linguistics. 6:11-47 Special Issue on "Directionality of Phrase Structure Building” ISSN: 22813128.

Suparman, Tatang. (2008). Proses Morfologis dalam Bahasa Indonesial. Bandung: Fakultas Sastra Unpad.

Sailor \& Mahajan.(2012). Toward a Derivational Typology. UCLA Working Papers in Linguistics, Theories of Everything Volume 17, Article 42: $367-381,2012$. This is an open-access article distributed under the terms of a Creative Commons

Non-Commercial

\section{License}

(http://creativecommons.org/lice nses/by-nc/3.0/).

Romli \& Wildan. (2015). Afiksasi Dalam Bahasa Indonesia dan Bahasa Sunda (Studi Kontrastif): Jurnal Sasindo Unpam, Volume 2, Nomor 2, Juli 2015.

Regel \& Opitz. (2018). Processing inflectional morphology: ERP evidence for decomposition of complex words according to the affix structure. Jurnal:Cortex DOI:10.1016/j.cortex.2018.10.003

Tambusai, Azhary et.all (2016).Morphological Typology of Affixes in Riau Malay. International Journal of Humanities and Social Science Vol. 6, No. 8; August 2016. ISSN 22208488 (Print), 2221-0989 (Online) (C)Center for Promoting Ideas, USA www.ijhssnet.com

Velupillai, Viveka. (2012). An Introduction to Linguistic Typology. Amsterdam: Jhon Benjamins Publishing Company.

Wiemer \& Serzant. (2017). Diachrony and typology of Slavic aspect: What does morphology tell us?.Björn Wiemer \& Ilja A. Seržant. 2017. Diachrony and typology of Slavic aspect: What does morphology tell us? In Walter Bisang \& Andrej Malchukov (eds.), Unity and diversity in rammaticalization scenarios, 239-307. Berlin: Language Science Press. (http:// OI:10.5281/zenodo.823246). 
Husni Thamrin was born in Baturaja on the fifth of January 1975. His Sarjana Degree (S1) is in English Department of STBA-YAPARI ABA Bandung. His Master Degree is Linguistic of UPI Bandung. Right now, $\mathrm{He}$ is still finishing his Dissertation of Linguistic Doctoral at UPI Bandung. He is as English Lecturer at English Department of the Faculty of Arts \& Letters (Fakultas IImu Seni \& Sastra) Bandung. Some books
\& articles that has been written by him as follows; Speech Act of a Person with Mental Disorders: A Clinical Pragmatic Analysis (2019); Sundanese Dialect in Sinar Resmi Traditional Village in Cisolok District, Sukabumi Regency (Phonological Perspective)(2020); Mutilasi Morfologi Pesan Teks Zaman Now(2018). 